\title{
SOX9 Gene
}

National Cancer Institute

\section{Source}

National Cancer Institute. SOX9 Gene. NCI Thesaurus. Code C75516.

This gene plays roles in transcription, osteogenesis, chondrogenesis and testis development. 